\title{
EXPERIMENTAL EVIDENCE FOR THE EXSOLUTION ORIGIN OF CRATONIC PERIDOTITE.
}

Canil, Dante.

\author{
Bayerisches Geoinstitüt, Universität Bayreuth, Postfach 10 12 51, D-8580 Bayreuth, Germany.
}

Geochemical analyses of several large peridotite xenoliths hosted in south African kimberlites indicate a clear compositional distinction between 'oceanic' and 'cratonic' lithosphere $(1,2)$. The petrologic processes which contributed to the compositional spectrum of relatively young 'oceanic' type lithosphere are fairly well understood, but those which have led to the compositional spectrum of ancient 'cratonic' lithosphere are still the subject of debate (1,3-5). Understanding the origin of cratonic lithosphere is important for models on mantle evolution, cratonization, and the origin of diamond within mantle lithosphere.

Coarse-grained garnet peridotites hosted in kimberlites erupted within the Archean Kaapvaal craton of southern Africa comprise the bulk of the 'cratonic' lithosphere beneath this region (1). Recent detailed petrographical analysis of coarse grained peridotites from southern Africa have noted a statistically significant spatial association of garnet and clinopyroxene with orthopyroxene (6). These observations have led to the hypothesis that all garnet and clinopyroxene in these rocks may have at one time been dissolved in orthopyroxene at temperatures higher than those now recorded by the xenoliths $(800-1200$ ${ }^{\circ} \mathrm{C}$ ). The probable compositions of these 'precursor' high temperature orthopyroxenes have been estimated by recombining the compositions of spatially associated orthopyroxeneclinopyroxene-garnet assemblages in the coarse grained peridotites studied. The resulting $\mathrm{Ca}, \mathrm{Al}$-rich high temperature orthopyroxenes are thought to have equilibrated with ultramafic melts at high pressures in the Archean mantle, but upon cooling to ambient temperatures, exsolved clinopyroxene and garnet to become the common low temperature coarse-grained garnet lherzolites recognized in many kimberlites emplaced within the Kaapvaal craton $(6,7)$. This exsolution process was enhanced by deformation in the mantle $(7)$ and it has been further proposed that many garnet lherzolites could have had a similar high temperature origin (6). Isotopic and bulk chemical considerations of garnet lherzolite samples from southern Africa are consistent with this proposal $(1,8)$, but there are as yet no experimental constraints on its credibility.

Phase equilibrium experiments in the system $\mathrm{CaO}-\mathrm{MgO}-\mathrm{Al}_{2} \mathrm{O}_{3}-\mathrm{SiO}_{2}-\mathrm{FeO}-$ $\mathrm{Cr}_{2} \mathrm{O}_{3}$ on typical 'oceanic' and 'cratonic' peridotite compositions, and a 'precursor' $\mathrm{Ca}, \mathrm{Al}-$ rich high temperature orthopyroxene composition were undertaken to test the feasibility of a high temperature 'exsolution' origin for garnet peridotites, and to provide further constraints on models for the origin of 'cratonic' lithosphere beneath southern Africa and possibly other Archean cratons. Starting compositions were estimates of average 'oceanic' and 'cratonic' peridotite, as given in Boyd (1) and a hypothetical $\mathrm{Ca}, \mathrm{Al}$-rich high temperature orthopyroxene similar to those presented in Cox et al (6). Experiments were performed on all three starting materials from pressures of 5 to $8 \mathrm{GPa}$ and temperatures of 1300 to $1600^{\circ} \mathrm{C}$ using a multi-anvil apparatus at the Bayerisches Geoinstitüt. Sectioned graphite heaters were used for all experiments to minimize thermal gradients to less than $20^{\circ} \mathrm{C} / \mathrm{mm}$. Starting materials were contained in graphite capsules. Run durations varied between 1 and 11 hours depending on temperature.

Equilibrium in the experiments was assumed based on the convergence of orthopyroxene, garnet and clinopyroxene compositions in all runs at the same pressure and temperature on two different peridotite starting compositions; 'oceanic' peridotite with high $\mathrm{Ca} / \mathrm{Al}$, low $\mathrm{Mg} / \mathrm{Fe}$ and 'cratonic' perditoite with low $\mathrm{Ca} / \mathrm{Al}$ and high $\mathrm{Mg} / \mathrm{Fe}$. In addition, 
reversals were performed at the lowest temperature $\left(1300^{\circ} \mathrm{C}\right)$ and therefore, 'worst case', of all experiments.

'Oceanic' peridotite crystallizes a garnet harzburgite assemblage at pressures and temperatures above $5 \mathrm{GPa}$ and $1450^{\circ} \mathrm{C}$, respectively, but at lower temperatures crystallizes clinopyroxene to become true lherzolite. 'Cratonic' peridotite crystallizes a garnet harzburgite assemblage at pressures above $5 \mathrm{GPa}$ and temperatures below $1450{ }^{\circ} \mathrm{C}$. Garnet-free harzburgite crystallizes from both 'cratonic' and 'oceanic' peridotite at temperatures above $1500^{\circ} \mathrm{C}$ and pressures at or below $5 \mathrm{GPa}$. Phase relations for the $\mathrm{Ca}, \mathrm{Al}$-rich orthopyroxene mimic those of 'oceanic' peridotite.

Phase equilibria for all three starting compositions confirm predictions $(6,7,9)$ that lherzolitic compositions actually become harzburgitic at high temperatures and/or pressures. At conditions of very high temperature and lower pressure near or above the peridotite solidus, both 'cratonic' and 'oceanic' peridotite would be bimineralic harzburgites consisting of only olivine and $\mathrm{Ca}, \mathrm{Al}$-rich orthopyroxene.

The comparison of experimental orthopyroxene compositions from this and other experimental studies on ultramafic compositions, with orthopyroxenes from natural south African lherzolite and harzburgite nodules $(2,6,10)$ and 'precursor' high temperature orthopyroxenes calculated from south African garnet lherzolites (6), provide some constraints on the probable conditions at which bimineralic harzburgites could have formed during the Archean, and how such rocks cooled (and exsolved) to become lherzolites.

In the 'cratonic' peridotite and $\mathrm{Ca}, \mathrm{Al}$-rich orthopyroxene starting compositions, orthopyroxenes not in equilibrium with garnet and/or clinopyroxene are similar to the hightemperature 'precursor' orthopyroxenes from which garnet and clinopyroxene are thought to have exsolved in the common low-temperature, coarse-textured garnet lherzolites from south African kimberlites. Thus, 'precursor' orthopyroxenes in these latter xenoliths could have equilibrated at maximum pressures of $5 \mathrm{GPa}$ near or slightly above the fertile mantle solidus $\left(1500-1600^{\circ} \mathrm{C}\right)$. At pressures above or temperatures below such conditions, the Al- and Casolubilities of these orthopyroxenes are exceeded, forming garnet and shifting their compositions more towards those typical of natural garnet harzburgites and lherzolites.

None of the orthopyroxenes produced in experiments reported herein have the high $\mathrm{Ca}$ and $\mathrm{Al}$ contents of the proposed 'precursor' orthopyroxenes for high temperature, porphyroclastic garnet peridotites. Calculated 'precursor' orthopyroxenes for the latter samples are too $\mathrm{Ca}$ - and Al-rich to have equilibrated with either typical 'cratonic' or 'oceanic' lherzolite bulk compositions under any P-T condition investigated $(>5 \mathrm{GPa})$. Samples from which these high $\mathrm{Ca}, \mathrm{Al}$ 'precursor' orthopyroxenes were constructed all have compositions characteristic of 'oceanic' lithosphere, whereas low temperature coarse-grained peridotites with calculated 'precursor' orthopyroxenes which match fairly well those observed in the experiments (discussed above), all have bulk compositions typical of 'cratonic' lithosphere.

In contrast, orthopyroxenes generated at lower pressure $(<3 \mathrm{GPa})$ above the peridotite solidus have compositions similar to the predicted 'precursor' high temperature orthopyroxenes for sheared 'oceanic' peridotites. Orthopyroxenes coexisting with ol+cpx+gt+liq at $3 \mathrm{GPa}$ and $1550^{\circ} \mathrm{C}(11)$ or at $2.5 \mathrm{GPa}$ and $1470^{\circ} \mathrm{C}(12)$, have the high $\mathrm{Ca}$ and $\mathrm{Al}$ contents predicted for the 'precursor' orthopyroxenes of 'oceanic' peridotite compositions. Using these constraints, orthopyroxenes parental to garnet and/or clinopyroxene in high temperature, porphyroclastic lherzolites having 'oceanic' compositions are predicted to have equilibrated above the peridotite solidus (1400 and 1600 ${ }^{\circ} \mathrm{C}$ ) at pressures less than $3 \mathrm{GPa}$. These conditions of formation for porphyroclastic samples with 'oceanic' compositions are remarkably similar to those predicted by Cox et al (6). 
Thus, the apparent cooling path for the presumed original high-temperature harzburgite protoliths of garnet lherzolites differs depending on bulk composition. The cooling history of high-temperature harzburgite protoliths parental to porphyroclastic 'oceanic' garnet lherzolite samples is complicated by the fact that such rocks originally formed at pressures less than $3 \mathrm{GPa}$, as indicated by their 'precursor' orthopyroxene compositions, but were sampled by their host kimberlite at pressures in excess of $6 \mathrm{GPa}$. The equilibration of the 'oceanic' lherzolites at pressures higher than those at which they are thought to have formed requires that mantle represented by these rocks was transported from shallower to deeper levels. It is speculated that such transport could have been accomplished by convective circulation of oceanic lithosphere, but that the convected mantle represented by these samples is ancient, because isotopic studies of these rocks indicate they were removed from the asthenosphere about 2.5 to $3.0 \mathrm{Ga}$ ago (8).

Compared to the porphyroclastic 'oceanic' lherzolites, the coarse textured 'cratonic' lherzolites have undergone a much simpler cooling history since their original formation. Parental orthopyroxenes from which clinopyroxene and garnet exsolved in 'cratonic' lherzolites appear to have formed at pressures near $5 \mathrm{GPa}$ and temperatures near or above the fertile peridotite solidus $\left(1500\right.$ to $\left.1800^{\circ} \mathrm{C}\right)$. At these $\mathrm{P}$ - T conditions along the fertile peridotite solidus, melts would have been ultramafic in composition $(10,13)$. The bulk compositions and isotopic characteristics of typical 'cratonic' lherzolites are best explained by Archean ultramafic liquid extraction from primitive mantle compositions such as pyrolite $(1,5,8)$. The compositional overlap between orthopyroxenes in equilibrium with olivine and melt along the liquidus of aluminum undepleted komatiite (14) and 'precursor'

orthopyroxenes for 'cratonic' coarse grained peridotites, is strong evidence for this scenario. Therefore, the P-T history of 'cratonic' lherzolite was probably one of simple isobaric cooling from formation temperatures near the peridotite solidus $\left(5 \mathrm{GPa},>1500^{\circ} \mathrm{C}\right)$ to those at which they were sampled in the mantle root of the Kaapvaal craton $\left(<1200^{\circ} \mathrm{C}\right)$.

In summary, phase equilibria from this and other experimental studies on ultramafic systems are consistent with an origin for 'cratonic' peridotite as a residue of Archean ultramafic liquid extraction, which has since cooled and exsolved clinopyroxene and garnet to become the common low temperature coarse-grained peridotite comprising the bulk of the Kaapvaal craton. This model may indeed apply to cratonic lithosphere underlying other less well studied (or well sampled) Archean cratons such as the Wyoming and/or Superior provinces in North America.

1. F.R. Boyd, Earth Planet. Sci. Lett., 96, 15-26, 1989.

2. F.R. Boyd and P.H. Nixon, Contrib. Mineral. Petrol., submitted

3. C. Herzberg, M. Feigenson, C. Skuba and E. Ohtani, Nature 332, 823-826, 1988.

4. S. E. Kesson and A.E. Ringwood, Chem. Geol.., 78, 97-118, 1989.

5. E. Takahashi, J. Geophys. Res., 95, 15941-15954,1990.

6. K.G. Cox, M.R. Smith and S. Beswetherick, in: Mantle Xenoliths, P.H. Nixon, ed., pp. 537-550, John Wiley and Sons, New York, N.Y. ,1987.

7. J.B. Dawson, J.V. Smith and R.L. Hervig, Phil. Trans. R. Soc. Lond., A297, 323$331,1980$.

8. R.J.Walker, R.W. Carlson, S.B. Shirey and F.R. Boyd, Geochim Cosmo Acta 53, 1583-1595, 1989.

9. M.J. O'Hara , M.J. Saunders, and E.L.P. Mercy, Phys. Chem. Earth, 9, 571-604, 1975.

10. P.H. Nixon, P.W.C. van Calsteren, F.R. Boyd and C.J. Hawkesworth, in: Mantle Xenoliths, P.H. Nixon, ed., pp. 523-533, John Wiley and Sons, New York, N.Y. ,1987.

11. E. Takahashi, J. Geophys. Res., 91, 9367-9382, 1986.

12. D. Elthon and C.M. Scarfe, Am. Miner., 69, 1-15, 1984.

13. E. Takahashi and C.M. Scarfe, Nature, 315, 566-568, 1985.

14. K. Wei, R.G. Tronnes and C.M. Scarfe, J. Geophys. Res., 95, 15817-15827, 1990. 